Abstracta Iranicacta Iranica

Revue bibliographique pour le domaine irano-aryen

Volume 25 | 2004

Comptes rendus des publications de 2002

\title{
« Non-Elamite Individuals in Achaemenid Persepolis ». Akkadica 123, (2002), pp. 145-152.
}

\section{Astrid Nunn}

\section{(2) OpenEdition}

1 Journals

\section{Édition électronique}

URL : http://journals.openedition.org/abstractairanica/4305

DOI : 10.4000/abstractairanica.4305

ISSN : 1961-960X

Éditeur :

CNRS (UMR 7528 Mondes iraniens et indiens), Éditions de l'IFRI

\section{Édition imprimée}

Date de publication : 15 mai 2004

ISSN : 0240-8910

\section{Référence électronique}

Astrid Nunn, « « Non-Elamite Individuals in Achaemenid Persepolis ». Akkadica 123, (2002), pp.

145-152. », Abstracta Iranica [En ligne], Volume 25 | 2004, document 80, mis en ligne le 15 mars 2006, consulté le 25 septembre 2020. URL : http://journals.openedition.org/abstractairanica/4305; DOI : https://doi.org/10.4000/abstractairanica.4305

Ce document a été généré automatiquement le 25 septembre 2020.

Tous droits réservés 
« Non-Elamite Individuals in Achaemenid Persepolis ». Akkadica 123, (2002), pp. 145-152.

\section{Astrid Nunn}

Les «Fortification tablets » ont surtout été écrites en élamite, mais aussi en araméen, babylonien, grec et phrygien. Les nombreux noms qui y apparaissent nous font percevoir le très grand mélange ethnique de la population persépolitaine et susienne à l'époque achéménide. L'A. analyse une liste de noms dont 19 sont akkadiens, 12 sémitiques de l'ouest, 2 égyptiens, 2 anatolico-grecs et 17 iraniens.

INDEX

Thèmes : 3.2.2. Pré-Achéménides et Achéménides

\section{AUTEURS}

ASTRID NUNN

Université de Munich 